Vol. 1 No. 3 November 2021 e-ISSN : 2797-1031 | p-ISSN : 2797-0744

\title{
PENGGUNAAN LEMBAR KERJA BERUPA TEKA TEKI SILANG DALAM UPAYA MENINGKATKAN HASIL BELAJAR IPA KELAS IX
}

\author{
ACHMAD SYAHREZA \\ SMP Islam Integral Luqman Al Hakim Batam \\ e-mail: achmadsyahreza21@guru.smp.belajar.id
}

\begin{abstract}
ABSTRAK
Penelitian ini dalam rangka untuk mengetahui pengaruh teka teki silang terhadap peningkatan hasil belajar IPA kelas IX di SMPI Integral Luqman Al Hakim Batam. Metode penelitian disusun dengan quasi experiment. Terdapat 2 tipe data yang diperoleh, yaitu (a)data primer berupa jawaban peserta didik dalam mengerjakan lembar kerja peserta didik berisi latihan dalam bentuk TTS, (b)data sekunder berupa studi literatur, wawancara, dan refleksi pembelajaran. Hasil penelitian ini menunjukkan adanya peningkatan hasil belajar, sehingga kedepannya menjadi salah satu pilihan karya dan inovasi pada pengembangan lembar kerja peserta didik yang memuat latihan soal.
\end{abstract}

Kata Kunci: Lembar Kerja Peserta Didik, Teka Teki Silang, Hasil Belajar

\begin{abstract}
This study was aimed to determine the effect of crossword puzzles on improving science learning outcomes for grade IX at SMPI Integral Luqman Al Hakim Batam. The research method was arranged in a quasi-experimental way. There are 2 types of data obtained, namely (a) primary data in the form of student answers in working on student worksheets containing exercises in the form of crossword puzzles, (b) secondary data in the form of literature studies, interviews, and learning reflections. The results of this study indicate an increase in learning outcomes, so that in the future it becomes one of the choices of work and innovation in the development of student worksheets that contain practice questions.
\end{abstract}

Keywords: Student Worksheets, Crosswords, Learning Outcomes

\section{PENDAHULUAN}

Kata pendidikan diartikan sebagai proses menjaga dan meningkatkan pengetahuan, keahlian, karakter dalam rangka mempersiapkan kehidupan yang lengkap ("Education", Webster New International Dictionary of The English Language, 1930: 700). Dalam khazanah pendidikan Islam dikenal dengan istilah tarbiyyah, ada 4 prinsip yang terkandung didalamnya, yaitu: (a)memelihara fitrah peserta didik, dan mengatur urusannya; (b)mengembangkan potensi dan mempersiapkannya; (c)mengarahkan fitrah dan semua potensinya menuju kebaikan dan kesempurnaan; (d)bertahap dalam prosesnya (an-Nahlawiy, 2007: 17). Proses ini sendiri meniscayakan adanya interaksi, dan interaksi harus berjalan dalam nuansa ilmiah yang inspiratif, kasih sayang, ramah, dan menyenangkan (al-Hijaziy, 1992: 3/228).

Diantara tanda keberhasilan pendidikan ialah peningkatan kualitas akal dan tingkah laku peserta didik. Akal yang dimaksud ialah cara untuk memikirkan sesuatu, yaitu cara untuk menilai sesuatu berdasarkan kaedah tertentu, sedangkan tingkah laku ialah cara yang digunakan untuk memenuhi tuntutan jasmani, naluri, interaksi alam dan sosial. Dua hal ini dapat diamati dan diukur, kualitas akal ialah kualitas pada ranah kognitif, adapun tingkah laku di sini ialah ranah afektif dan psikomotorik.

Dalam pembelajaran ada latihan atau tugas untuk meninjau apa yang telah dipelajari, meningkatkan daya ingat, dan mengasah ketajaman berpikir. Ini merupakan upaya untuk menunjang tercapainya keberhasilan pendidikan, diantaranya terwujudnya kualitas akal peserta didik yang baik. Dan diantara indikasinya ialah adanya peningkatan prestasi belajar peserta didik. Memberikan latihan terhadap peserta didik pernah dicontohkan oleh Nabi Muhammad, kemudian Beliau memuji hasil yang diperoleh (Abu Ghuddah, 1996: 154). Ada banyak bentuk 
latihan, dan teka teki silang merupakan salah satu pilihan yang bernuansa permainan, menyenangkan dan dapat mengundang partisipasi aktif peserta didik (Susilaningsih, 2009: 3).

Berdasarkan uraian di atas, diambil salah satu upaya untuk meningkatkan hasil belajar peserta didik dengan menggunakan lembar kerja yang berisi latihan dalam bentuk teka teki silang. Mengingat pembelajaran di sekolah secara umum masih menggunakan metode ceramah, dan untuk pelajaran IPA belum menggunakan lembar kerja peserta didik yang berisi latihan dalam bentuk permainan seperti teka teki silang, sehingga pembelajaran yang melibatkan peserta didik secara aktif melalui penggunaan teka teki silang menjadi inovasi yang relevan dan perlu diketahui pengaruhnya terhadap hasil belajar. Teka teki silang sendiri ialah suatu permainan yang mengharuskan peserta didik mengisi ruang kosong dengan huruf-huruf yang membentuk suatu kata berdasarkan petunjuk yang tersedia. Petunjuknya sendiri terbagi menjadi kategori mendatar dan menurun.

Dalam pembelajaran IPA di SMPI Integral Luqman Al Hakim peserta didik diberikan bahan ajar dan lembar kerja yang dipersiapkan guru, disertai dengan latihan, diantaranya dalam bentuk teka teki silang, dan model pembelajaran di kelas dengan Discovery Learning. Dengan diterapkannya upaya ini secara maksimal, hasil belajar peserta didik mengalami peningkatan sehingga turut andil dalam menunjang keberhasilan pendidikan khususnya di bidang Ilmu Pengetahuan Alam di lingkungan sekolah.

\section{METODE PENELITIAN}

Pendekatan dalam penelitian ini ialah quasi experiment yang melibatkan sampel 51 peserta didik, dengan desain one group pretest-posttest. Alasan menggunakan metode ini karena tujuannya untuk melakukan perbandingan suatu akibat perlakuan tertentu dengan perlakuan lain yang berbeda. Sumber data dalam penelitian ini ialah data primer dan data sekunder. Data primer diperoleh dari peserta didik, jenisnya data kuantitatif berupa skor. Adapun data sekunder didapat dari literatur yang berhubungan dengan tema penelitian. Data yang dikumpulkan peneliti berupa hasil pretest, posttest, wawancara, dan refleksi pembelajaran.

Tahapan analisis peningkatan hasil belajar dilakukan melalui langkah : (a)mencari nilai gain ternormalisasi (Hake, 1998 : 65) melalui rumus

$$
\text { Gain standart }=\frac{\text { skor posttest }- \text { skor pretest }}{\text { skor maksimum }- \text { skor pretest }}
$$

(b)menjumlahkan gain ternormalisasi untuk mendapatkan reratanya; (c)menentukan efektifitas penggunaan teka teki silang berdasarkan kriteria: (1) tinggi, jika $\mathrm{g} \geq 0,7$; (2) sedang, jika0,7 > $\mathrm{g} \geq 0,3$; serta (3) rendah, jika $\mathrm{g}<0,3$; (d)mencari $p$-value melalui $t$-tes untuk mengetahui tingkat signifikansi hipotesis. Adapun langkah-langkah kegiatannya bermula dari persiapan, pelaksanaan dan penyusunan.

\section{HASIL DAN PEMBAHASAN}

\section{Hasil}

Penelitian pendahuluan ialah studi literatur dengan hasil berupa informasi mengenai lembar kerja peserta didik, teka teki silang, pembelajaran IPA dan upaya peningkatan hasil belajar yang diperoleh dari modul, buku, dan jurnal. Berdasarkan tes awal sebelum diberikan perlakuan dan setelah diberikan tindakan diperoleh hasil sebagai berikut;

Tabel 1. Hasil belajar kelas sebelum dan sesudah diberi perlakuan

\begin{tabular}{clcc}
\hline No. & Hasil & Pretest & Posttest \\
\hline 1. & Rata-rata & 78,96 & 95,29 \\
2. & Nilai tertinggi & 89 & 100 \\
3. & Nilai terendah & 60 & 75 \\
4. & \% Ketuntasan & 92,16 & 100 \\
\hline
\end{tabular}


Dan nilai rerata gain untuk hasil belajar peserta didik sebesar 0,776. Ini menunjukkan bahwa peningkatan hasil belajar peserta didik dengan kategori tinggi. Adapun hasil pengujian t-tes diperoleh $p$-value sebesar 0,000. Jika p-value kurang dari 0,05 maka hipotesis signifikan, artinya terjadi perubahan yang signifikan antara hasil belajar peserta didik sebelum dan sesudah menggunakan lembar kerja berupa teka teki silang. Sehingga dapat dikatakan bahwa hasil belajar peserta didik dengan penggunaan teka teki silang lebih baik dari hasil belajar tanpa menggunakan teka teki silang dalam pembelajaran Ilmu Pengetahuan Alam di SMPI Integral Luqman Al Hakim kelas IX.

\section{Pembahasan}

Berdasarkan nilai rerata gain sebesar 0,776 menunjukkan adanya peningkatan hasil belajar peserta didik, dan dengan t-tes diperoleh p-value (2-tailed) 0,000, nilai ini kurang dari 0,05 yang menunjukkan bahwa hasil belajar peserta didik dengan menggunakan teka teki silang lebih baik dari hasil belajar tanpa teka teki silang dalam pembelajaran Ilmu Pengetahuan Alam yang dilaksanakan di SMPI Integral Luqman Al Hakim Batam.

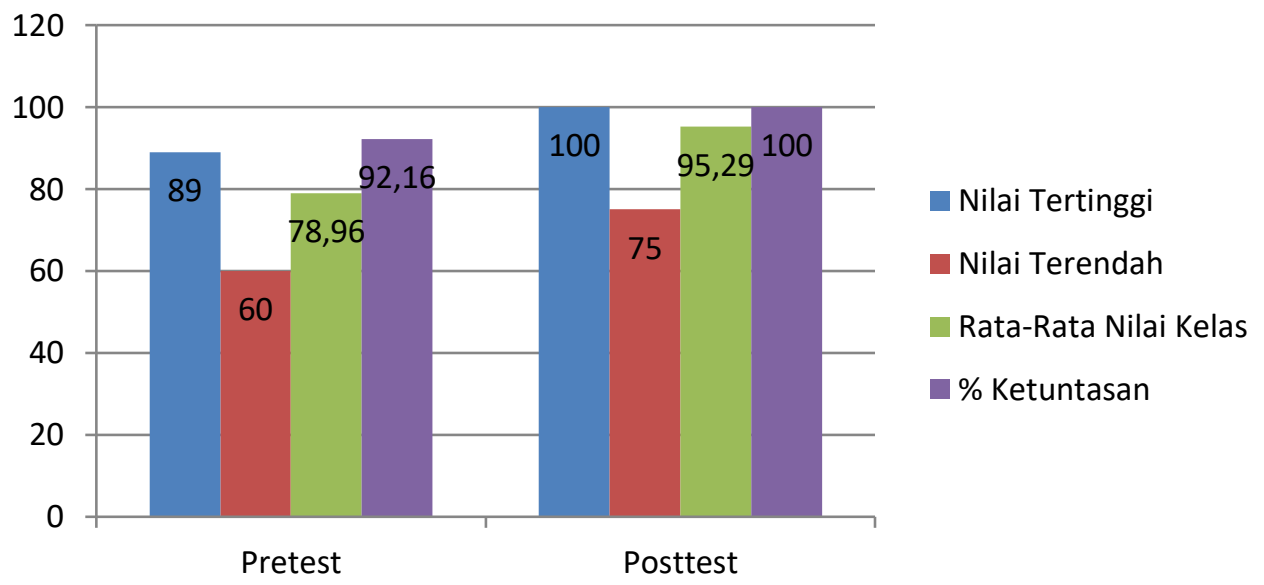

Gambar 1. Hasil belajar pretest dan posttest

Berdasarkan hasil penelitian diperoleh data bahwa sebelum penggunaan teka teki silang peserta didik mampu mencapai ketuntasan sebesar $92.16 \%$. Akan tetapi, penggunaan teka teki silang lebih baik daripada pembelajaran tanpa menggunakannya, hal ini ditunjukkan dengan rata rata kelas sebelum perlakuan ialah 78,96 , sedangkan sesudah diberi perlakuan sebesar 95,29 . Hal ini karena teka teki silang merupakan permainan yang menyenangkan, mengundang partisipasi aktif peserta didik, dan merupakan fasilitas yang dengannya peserta didik meninjau apa-apa yang telah dipelajari (Martinez, 2011: 7).

Berdasarkan karakter petunjuk dan isian teka teki silang didapati bahwa tingkatan pengetahuan yang melalui permainan TTS berada pada C1 (remember) dan C2 (understand) menurut taksonomi Bloom yang telah direvisi. Meskipun demikian, teka teki silang membantu peserta didik dalam meningkatkan kemampuan mengingat pada proses pembelajaran (Akhmedjanova, 2021: 169). Kemampuan mengingat dan memahami sendiri merupakan kemampuan dasar yang penting dalam mendukung proses pemecahan masalah.

Berdasarkan wawancara dan refleksi pembelajaran diketahui bahwa $98 \%$ peserta didik menyukai pembelajaran yang disertai dengan permainan teka teki silang. Peserta didik terlibat aktif dalam mengerjakan teka teki silang, dan turut membantu sesama yang mengalami kesulitan.

\section{KESIMPULAN}

Berdasarkan hasil penelitian dan pembahasan yang telah diuraikan, peneliti menarik kesimpulan sebagai berikut: 
1. Penggunaan lembar kerja berupa permainan teka teki silang meningkatkan hasil belajar IPA peserta didik kelas IX di SMPI Integral Luqman Al Hakim. Hal ini dilihat dari ratarata kelas setelah diberikan perlakuan lebih tinggi daripada sebelumnya, dan demikian juga dengan ketuntasan belajar peserta didik setelah menggunakannya lebih tinggi.

2. Penggunaan lembar kerja berupa permainan teka teki silang memfasilitasi peserta didik untuk terlibat aktif dalam proses pembelajaran. Hal ini berdasarkan pengamatan peneliti, peserta didik lebih aktif dalam proses pembelajaran saat menggunakan teka teki silang dibanding dengan sebelum menggunakannya.

3. Penggunaan lembar kerja berupa permainan teka teki silang dalam pembelajaran disukai oleh peserta didik. Hal ini dilihat dari hasil wawancara dan refleksi pembelajaran, dimana $98 \%$ peserta didik menyatakan suka terhadap penggunaannya

\section{DAFTAR PUSTAKA}

Abu Ghuddah, A. F. (1996). ar-Rasul al-Mu'allim. Aleppo : Maktabah al-Mathbu'at alIslamiyyah

Akhmedjanova, D. A. (2021). Effective Ways Of Improving Memory In Learning Process. Scientific Journal Impact Factor, Vol. 2 Issue 5 pp. 167-170

Al-Hijaziy, Muhammad Mahmud. (1992). Tafsir al-Wadhih. Beirut : Dar al-Jail al-Jadid

An-Nahlawiy, Abdurrahman. (2007). Ushul al-Tarbiyyah al-Islamiyyah wa Asalibuha fil Bait wal Madrasah wal Mujtama'. Beirut : Dar al-Fikr

Hake, Richard R. (1998). Interactive Engagement Versus Traditional Methods:Asixthousandstudent Survey of Mechanics Test Data for Introductory Physics Course. Am. J. Phys. $66(1)$

Martinez Serna, M. I., \& Parra Azor, J. F. (2011). Active Learning: Creating Interactive Crossword Puzzles. Congreso Internacional De Innovacion Docente Universidad Politecnica De Cartagena.

Springfield, Mass., U.S.A. (1930). Webster's New International Dictionary Of The English Language. G. \& C. Merriam Company

Susilaningsih, E. (2009). Efektivitas Penerapan Teka-Teki Silang pada Hasil BelajarSiswa Materi Pokok Sistem Pencernaan Makanan di SMP Islam 2 Mondokan. Jurnal Pendidikan. Semarang: Universitas Negeri Semarang. 